\title{
Meninjau Hukuman Mati Bagi Murtad (Kajian Hadist Tematik)
}

\author{
M. Robith Fuadi Abdullah \\ Fakultas Syariah UIN Maulana Malik Ibrahim Malang \\ Email: assidariji@yahoo.com
}

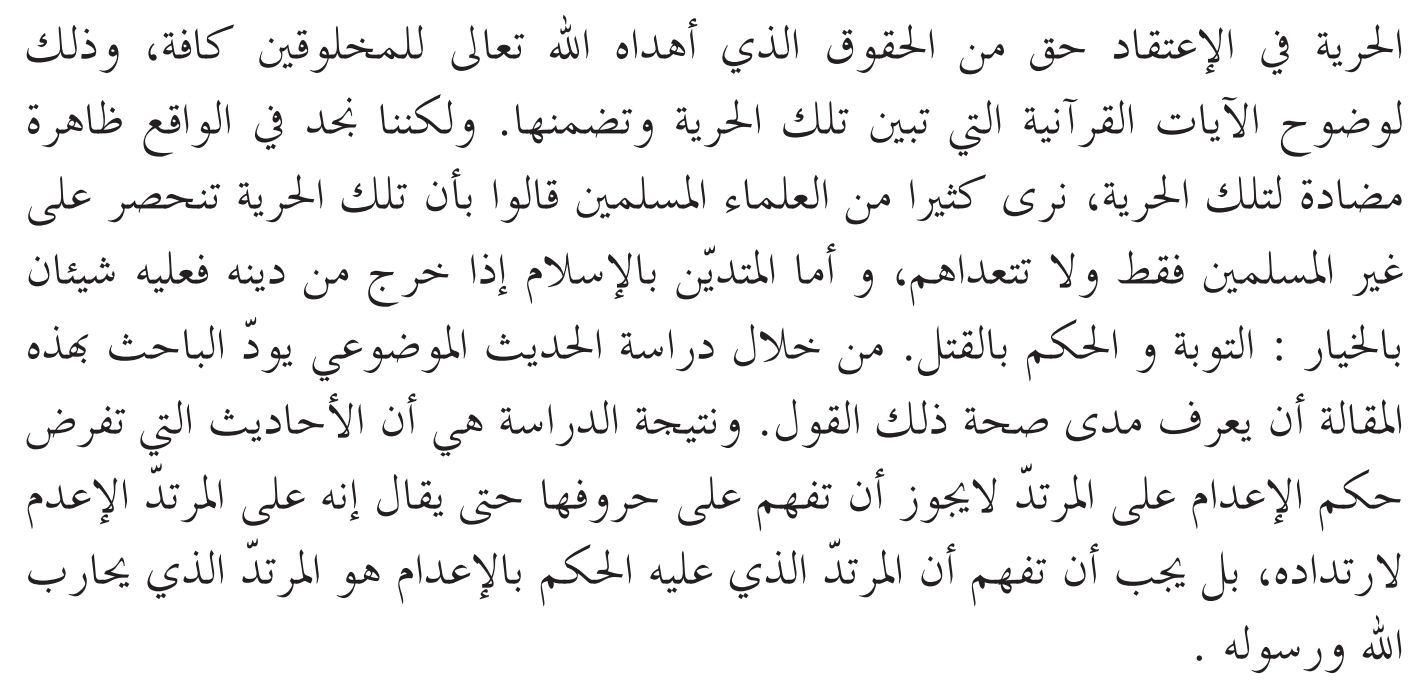

Kebebasan beragama adalah hal absolut yang diberikan oleh Allah Swt kepada manusia, karena ayat-ayat al-Qur'an yang menerangkan tentang kebebasan beragama sangat terang dan jelas adanya. Namun, pada prakteknya kita menemui fenomena yang sangat kontradiksi. Banyak ilmuwan Islam yang menyatakan bahwa kebebasan beragama tersebut berlaku bagi orang non muslim. Sedangkan bagi seorang muslim, apabila ia keluar dari agama Islam, maka baginya dua pilihan yakni taubat atau hukuman mati. Dengan melakukan kajian Hadist tematik, tulisan ini bermaksud untuk mengecek validitas pendapat para ilmuwan muslim tentang hukuman mati bagi murtad. Hasil dari penelitian ini dapat disimpulkan bahwa hadits tentang hukuman mati bagi orang murtad tidak bisa difahami secara harfiah sehingga setiap orang murtad wajib dibunuh. Namun harus difahami beserta konteksnya, yaitu bahwa orang murtad yang boleh dibunuh adalah orang murtad yang memerangi Allah dan Rasul-Nya.

Kata Kunci: Murtad, Hukuman mati, Hadits

Allah berfirman dalam al-Qur'an:

$$
\text { لا إكراه فن الدين قد تبين الرشد من الغي } 1
$$

${ }^{1}$ (QS. Al-Baqarah[2]:253)

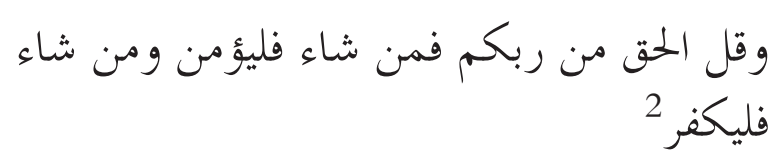

Melalui firman di atas, Allah swt. Tuhan

${ }^{2}$ (QS.Al-Kahfi[18]:30) 
semesta alam, ingin menyampaikan pesan yang teramat penting bagi makhluk sekalian. Bahwa kebebasan dalam berkeyakinan atau beragama adalah hal yang absolut yang diberikan oleh Allah swt. kepada makhluk sekalian. Ketentuan tersebut tidak akan berubah sampai kapanpun, di manapun dan dalam kondisi apapun. Dikatakan demikian karena ayat-ayat al-Qur'an yang menerangkan tentang kebebasan beragama sangat terang dan jelas adanya.

Namun, pada prakteknya kita menemui fenomena yang sangat kontradiksi dengan ketentuan tentang kebebasan beragama sebagaimana yang telah di gariskan oleh Allah swt. Sangat banyak ilmuwan islam yang menyatakan bahwa kebebasan beragama tersebut berlaku bagi orang non muslim. Artinya, seorang non muslim, bebas menetukan sikap, apakah akan menjadi seorang muslim, nasrani, yahudi, hindu, budha atau yang lainnya. Sedangkan bagi orang yang sudah masuk Islam, maka akan berlaku baginya sebuah ketentuan hukum tersendiri. Hukum tersebut menyatakan bahwa barang siapa keluar dari agama Islam, maka baginya dua pilihan yakni taubat atau hukuman mati. Hal ini didasarkan pada sebuah Hadist yang tidak perlu ditanyakan lagi kesahihan sanadnya.

Bermula dari fenomena kontradiksi antara pesanal-Qur'antentangkebebasanberakidah, dan realita hukum yang ditetapkan oleh para ilmuwan Islam tentang hukuman bagi orang murtad, dalam tulisan ini, penulis akan mencoba untuk mengulas dan menimbang kembali dasar hukum ketentuan di atas, dengan melakukan kajian Hadist tematik. Pengkajian tersebut dimaksudkan untuk mendapatkan gambaran yang lebih utuh tentang sikap Hadist terhadap orang yang keluar dari agama Islam (murtad).

Setelah melakukan pengecekan terhadap Hadist-hadist yang berkaitan tentang hukuman bagi orang murtad, maka ditemukan beberapa Hadist yang tampaknya saling bertentangan. Untuk itu, penulis akan menge- lompokkan Hadist-hadist tersebut menjadi dua kelompok. Kelompok pertama, berisikan Hadist-hadist yang tidak memberikan vonis hukuman mati terhadap orang murtad. Hadist-hadist ini akan dikelompokkan di bawah payung Hadist ushul. Sedangkan kelompok selanjutnya, adalah Hadist khushum, yang memuat Hadist-hadist tentang hukuman mati bagi orang yang keluar dari agama Islam (murtad).

Berikut ini adalah Hadist-hadist berkaitan tentang hukuman bagi orang murtad yang dapat penulis kumpulkan, baik itu Hadist ushul maupun khushum. Hadist-hadist tersebut sengaja penulis cantumkan lengkap dengan sanadnya agar pembaca bisa melihat dengan utuh rangkain perawinya, sehingga bisa menilai kualitas Hadist-hadist tersebut. Disamping itu, agar pembaca semakin yakin dengan kualitas Hadist-hadist yang terkumpul, penulis mencamtumkan beberapa penilaian ulama Hadist terhadap beberapa Hadist, terutama terhadap Hadist yang tidak diambil dari kitab Shahih al-Bukhari dan Shahih al-Muslim.

\section{Hadist Ushul}

1. Hadist Shahih al-Bukhari tentang seorang badui yang ingin keluar dari bai' at Islam.

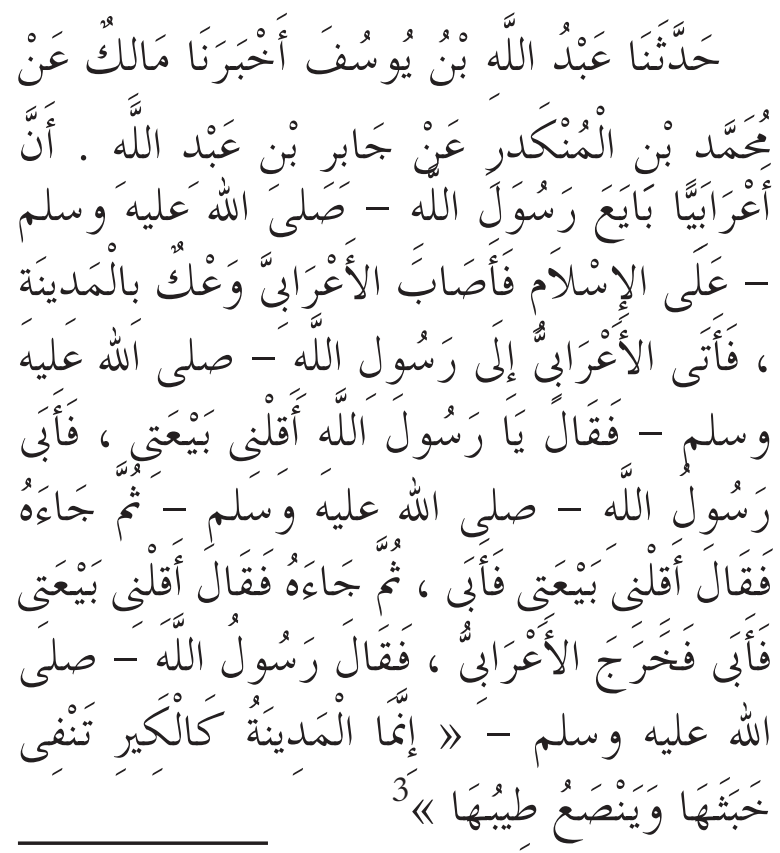

${ }^{3}$ Al-Bukhâri, Shahîh al-Bukhâriý, Hadith nomor 7211. 
Dalam kitab al-Jâmi' al-Kabîr, Suyuthi menyebutkan bahwa Hadist di atas diriwayatkan oleh Thabrani, Ibnu Abi Syaibah, Ahmad, Bukhari, Muslim, Turmudzi, Nasa'i, dan Ibnu Hibban. Kesemuanya dari sahabat Jabir bin 'Abdullah. ${ }^{4}$ Imam Turmudzi berkata, bahwa dalam bab ini juga terdapat Hadist yang diriwayatkan dari Abu Hurairah. Turmudzi memberikan komentar bahwa Hadist ini hasan shahih. Al-Albani juga berkomentar bahwa Hadist ini sahih. ${ }^{5}$

2. Hadist Shahih al-Bukhâriy tetang sulh alhudaybiyah:

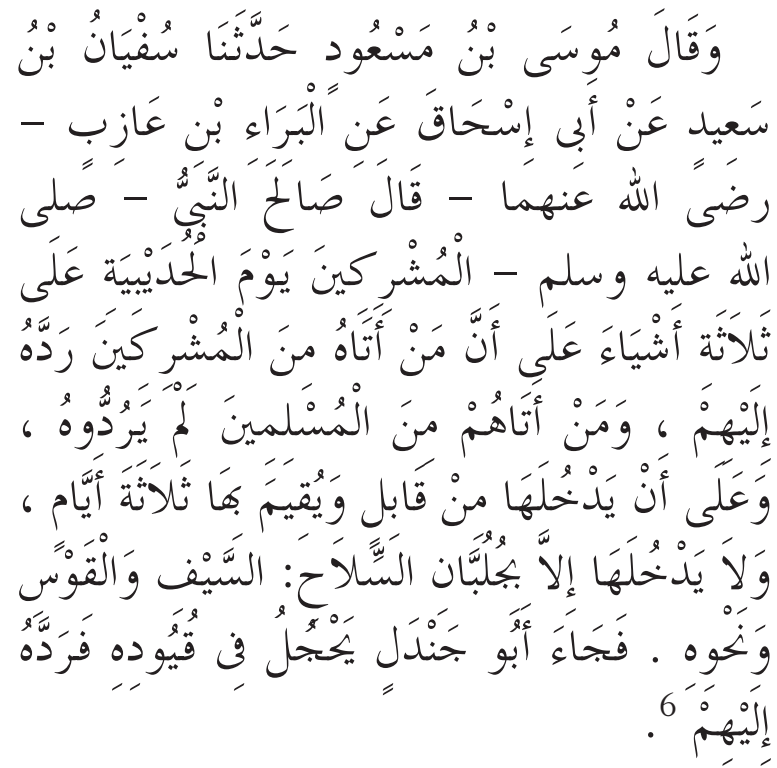

3. Rasulullah melarang 'Umar membunuh 'Abdullah bin Ubay.

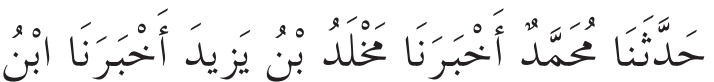

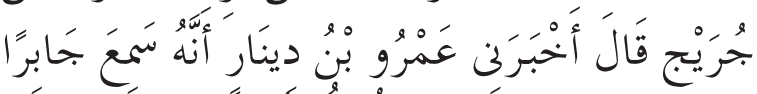

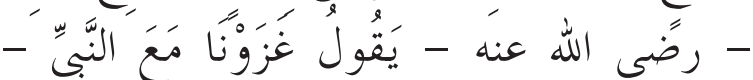

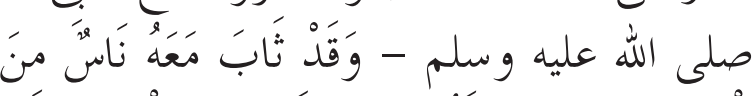

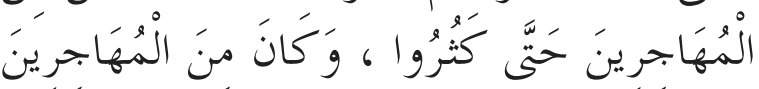

${ }^{4}$ Suyuthi, al-Jami' al-Kabir, Hadith nomor 2958.

${ }^{5}$ Turmudzi, Sunan al-Turmudzi, vol. 5, (Bairut: Dar Ihya $>$ al-Turath al->Arabi, tt), h. 720, Hadith nomor 3920.

${ }^{6}$ Al-Bukhari, Shahih al-Bukhari, Hadith nomor 2700. Hadith ini juga diriwayatkan oleh Baihaqi dalam Sunan al-Baihaqi, vol. 14 (Bairut:Dar al-Fikr, tt), h. 95, Hadith nomor 19206.

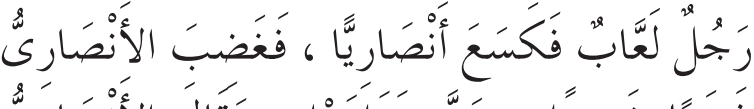

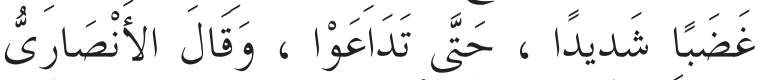

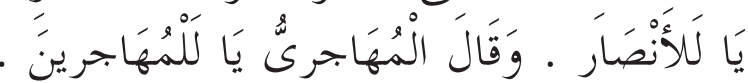

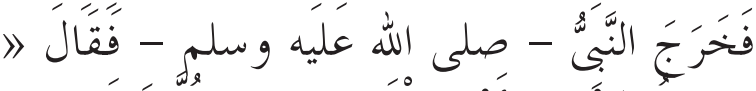

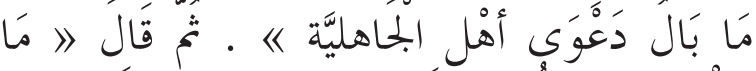

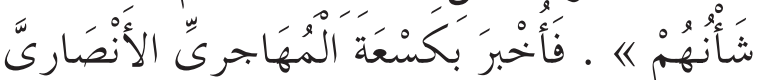

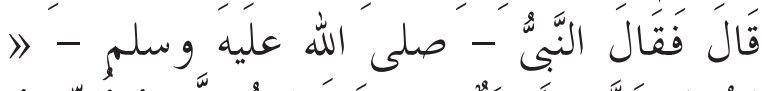

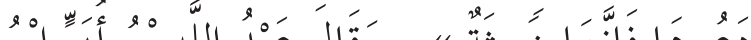

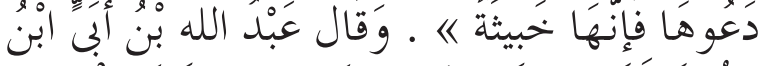

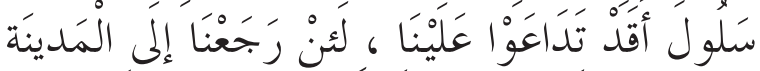

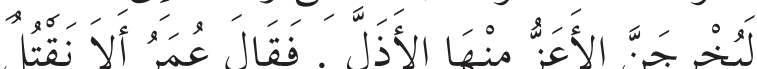

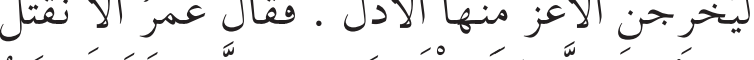

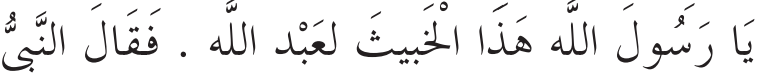

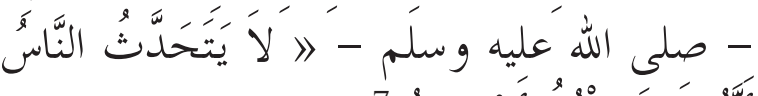

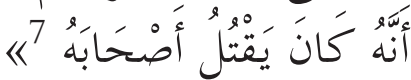

4. Kisah seorang nasrani yang memeluk agama Islam dan menjadi salah satu penulis wahyu, tapi kemudian ia keluar dari agama Islam dan menjadi seorang nasrani kembali.

Shahîh al-Bukhâriy:

حدثنا أبو معمر حدثنا عبد الوارث حدثنا

عبد العزيز عن أنس رضي الله عنه قال : كان رجل نصر انيا فأسلم وقرأ البقرة و آل عمران فكان يكتب للنبي صلى الله عليه و سلم فعاد نصر انيا فكان يقول ما يدري محمد إلا ما كتبت له فأماته الله فلفنوه فأصبح وقائ لفظته الأرض مض فقالوا هذا فعل محمد وأصحابه للا هرب منهـم نبشوا عن صاحبنا فألقوه فحفروا له فأعمقوا فأصبح وقل لفظته الأرض فقالوا هذا فعل محمد وأصحابه نبشو اعن صاحبنا لما هر بـ منهم فألقوه فحفروا له وأعمقوا له في الأرض ما استطاعوا فأصبح وقل لفظته الأرض فعلموا أنه ليس من

${ }^{7}$ Al-Bukhari, Shahih al-Bukhari, Hadith nomor 2584. 


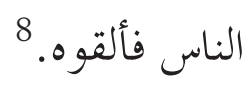

Hadist inijuga diriwayatkan oleh, Muslim, Ahmad, Humaidi, dan Turmudzi. Turmudzi berkata: ini Hadist hasan sahih. ${ }^{9}$

\section{Hadist Khusum}

1. Hadist Sahih al-Bukhari yang berbunyi: "Barang siapa merubah agamanya maka bunuhlah dia."

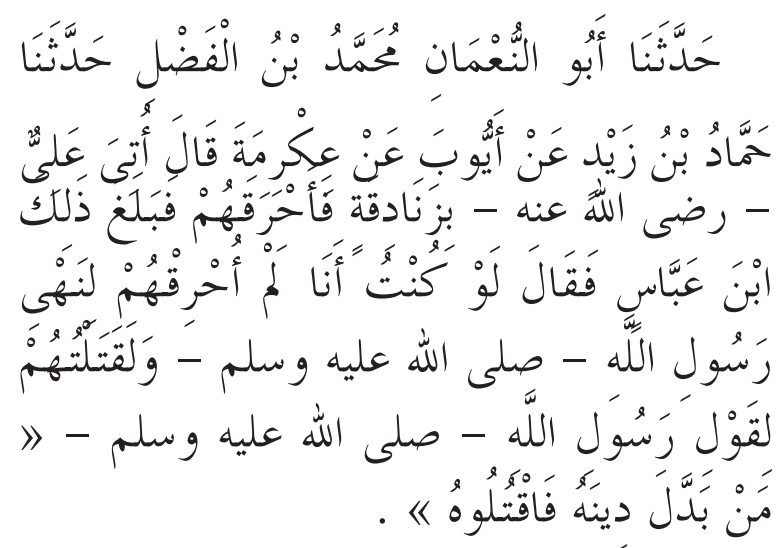

Sunan al-Turmudzi:

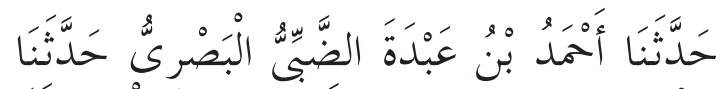

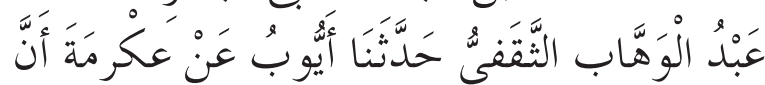

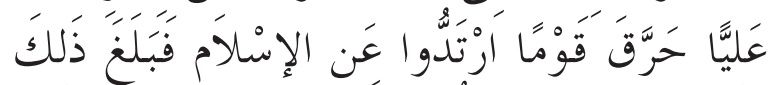

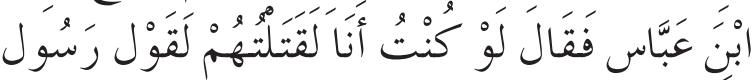

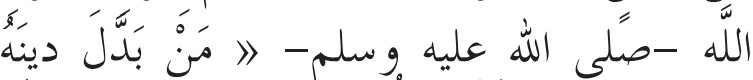

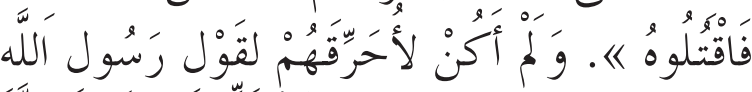

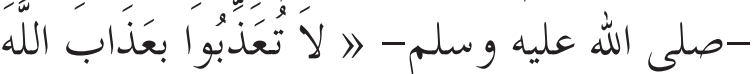

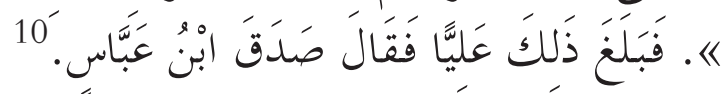

Abu isa al-Turmudzi berkata bahwa ini shahih hasan. Para ilmuwan muslim mengaplikasikan hukum tersebut bagi orang murtad. Akan tetapi mereka berbeda pendapat apabila si murtad adalah seorang

${ }^{8}$ Al-Bukhari, Shahih al-Bukhari, Hadith nomor 3617. Hadith tersebut juga diriwayatkan oleh Muslim pada Hadith nomor 2781.

'Suyuthi, al-Jami' al-Kabir, Hadith nomor 12563.

${ }^{10}$ Turmudzi, Sunan al-Turmudzi, vol. 6, h. 43, Hadith nomor 1530. wanita, dimana sebagian ulama' -seperti Auza'i, Ahmad dan Ishaq- berpendapat bahwa hukum mati juga berlaku bagi perempuan yang murtad, sebagian yang lain -seperti Sufyan al-Tsauri dan para ulama' Kufah-berpendapat bahwa perempuan yang murtad tidak dihukum mati, melainkan dipenjara saja. ${ }^{11}$

Musnad Ahmad bin Hanbal:

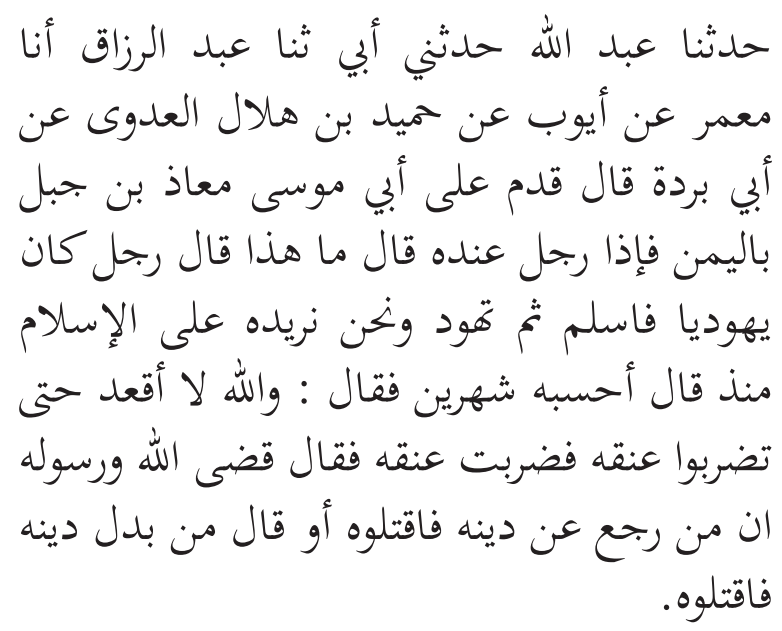

Syaikh Syu'aib al-Arna'uth memberikan komentar bahwa Hadist di atas mempunyai sanad yang sahih, para perawinya adalah perawi yang tsiqah semua dan tergolong para perawinya imam Bukhari dan Muslim. ${ }^{12}$ Imam Suyuthi menyebutkan bahwa Hadist ini diriwayatkan oleh al-Thayalisi, Ahmad, Ibnu Abi Shaibah, Bukhari, Abu dawud, Turmudzi, Nasa'i, Ibnu Hibban dan Ibnu Majah dari sahabat Ibnu Abbas. Disamping itu, hadits tesersebut juga diriwayatkan oleh Abd al-Razaq, Ibnu Abi Shaibah, Ahmad dari sahabat $\mathrm{Mu}^{\prime} \mathrm{adz}$, dan al-Daruqutni dari sahabat Abu Bakar. ${ }^{13}$

2. Haram membunuh seorang muslim, kecuali apabila ada tiga perkara yang membolehkan/membenarkan pembunuhan tersebut.

\section{Sahih Muslim:}

\footnotetext{
${ }^{11}$ Ibid, vol 6, h. 43.

${ }^{12}$ Ahmad, Musnad Ahmad bin Hanbal, vol. 5 (Kairo: Muassasah Qarthabah, tt), h. 231, Hadith nomor: 22068. ${ }^{13}$ Suyuthi, al-Jami> al-Kabir, Hadith nomor 4379.
} 


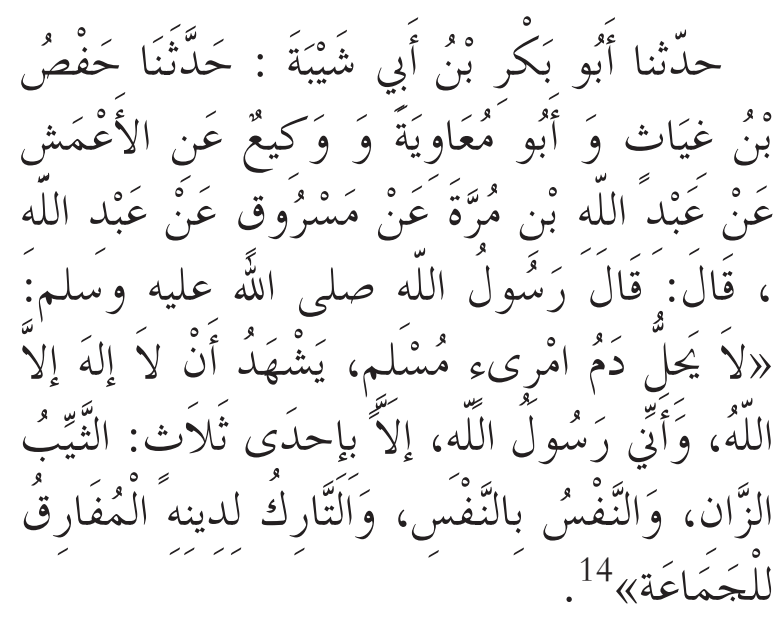

Hadist ini diriwayatkan oleh 'Abd alRazzaq, Ahmad, Ibnu Abi Syaibah, Bukhari, Muslim, Abu Dawud, Turmudzi, Nasa'i dan Ibnu Majah dari sahabat Abdullah bin Mas'ud ${ }^{15}$.

Sunan al-Nasa'i :

أخبرنا أحمد بن حفص بن عبد الله قال حدثني

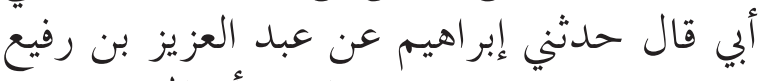

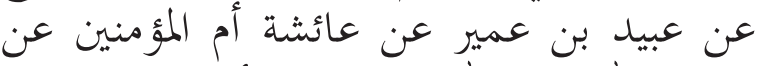

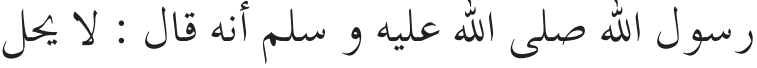

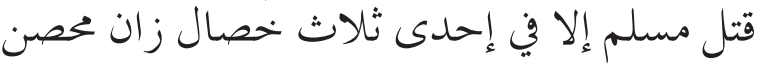

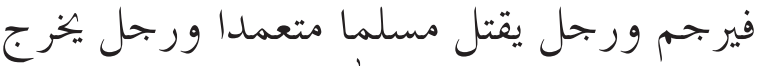

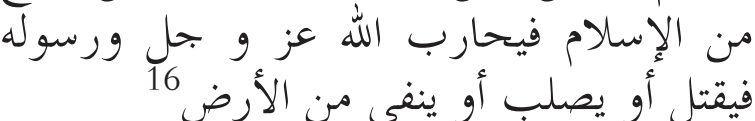

Syaikh al-Albani memberikan kometar bahwa Hadist ini adalah Hadist sahih. ${ }^{17}$

\section{Analisa Matan Hadist}

Dari paparan Hadist di atas, kita dapat mengambil kesimpulan tentang adanya kontradiksi antara Hadist khushum yang menyatakan bahwa orang yang keluar dari agama Islam harus dihukum mati. Sedangkan pada Hadist ushul ditemukan bahwa dalam

\footnotetext{
${ }^{14}$ Muslim, Sahih Muslim, vol. 11, h. 138, Hadith nomor 4329 .

${ }^{15}$ Suyuthi, al-Jami' al-Kabir, Hadith nomor 1627.

${ }^{16}$ Nasa'i, al-Mujtaba min al-Sunan, vol. 8, Maktab alMatbu'at al-Islamiyah, 1986, h. 23 Hadith nomor. 4743

${ }^{17} \mathrm{Ibid}$. h. 23 Hadith nomor. 4743.
}

beberapa kesempatan -sebagaimana Hadisthadist di atas- orang yang keluar dari agama Islam tidak dihukum mati.

Para ilmuwan Hadist telah merumuskan beberapa hal untuk dijadikan landasan dalam memahami Hadist secara benar. Diantaranya adalah memahami Hadist sesuai dengan tuntunan yang termuat dalam al-Qur'an, ${ }^{18}$ karena merupakan penjelas bagi al-Qur'an, dan selamanya tidak akan bertentangan dengan al-Qur'an, dan mengumpulkan HadistHadist yang membicarakan satu tema tertentu untuk kemudian melakukan al-jam'u ataupun al-tarjih, ataupun al-nasikh wa'lmansukh. ${ }^{19}$

\section{Ketentuan Murtad dalam Al-Qur'an}

Al-Qur'an sebagai pedoman hidup dan sumber hukum Islam, telah menjelaskan berbagai hal dalam kehidupan manusia, termasuk hukuman bagi orang yang wajib dikenai sanksi karena telah melakukan pelanggaran-pelanggaran. Sebagai contoh, orang yang mencuri, maka baginya hukum potong tangan baik pencuri tersebut laki-laki maupun perempuan.

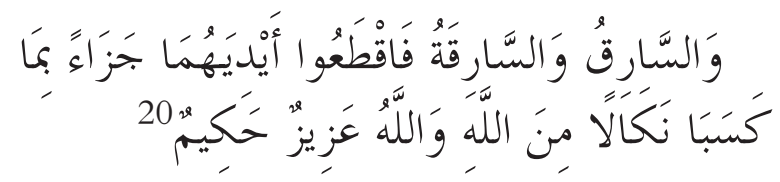

Dalam ayat lain Allah juga menjelaskan hukuman cambuk seratus kali yang berlaku bagi orang yang berzina, baik ia laki-laki maupun perempuan.

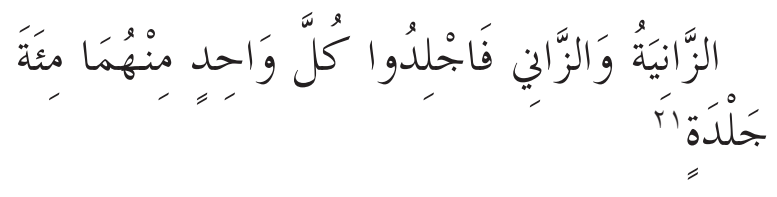

Kalau kita mencermati ayat-ayat di atas, maka bisa diambil kesimpulan bahwa Allah

${ }^{18}$ Muhammad Al-Ghazali, Al-Sunnah al-Nabawiyyah baina Ahl al-Figh wa Ahl al-Hadith (Kairo: Dar al-Syuruq, 2009), h. 23; Yusuf Al-Qardlawi, Kayfa Nata'amal ma'a al-Sunnah al-Nabawiyyah (Kairo: Dar al-Syuruq, 2000), h. 45

${ }^{19}$ Mahmud Thahhan, Taysir Musthalah al-Hadith (Maktabah al-Ma'arif, 2004), h. 72.

${ }^{20}$ (QS. Al-Ma'idah[5]:39)

${ }^{21}$ (QS. An-Nur[24]: 3) 
telah menjelaskan balasan-balasan bagi orang yang melakukan pelanggaran, bahkan dijelaskan secara terperinci dengan menyebutkan bahwa hukum tersebut berlaku bagi laki-laki dan perempuan. lalu bagaimana dengan hukuman bagi orang murtad, ketentuan apa yang ditetapkan oleh Allah bagi orang murtad.

Berikut ini adalah ayat-ayat yang menjelaskan tentang hukuman bagi orang murtad:

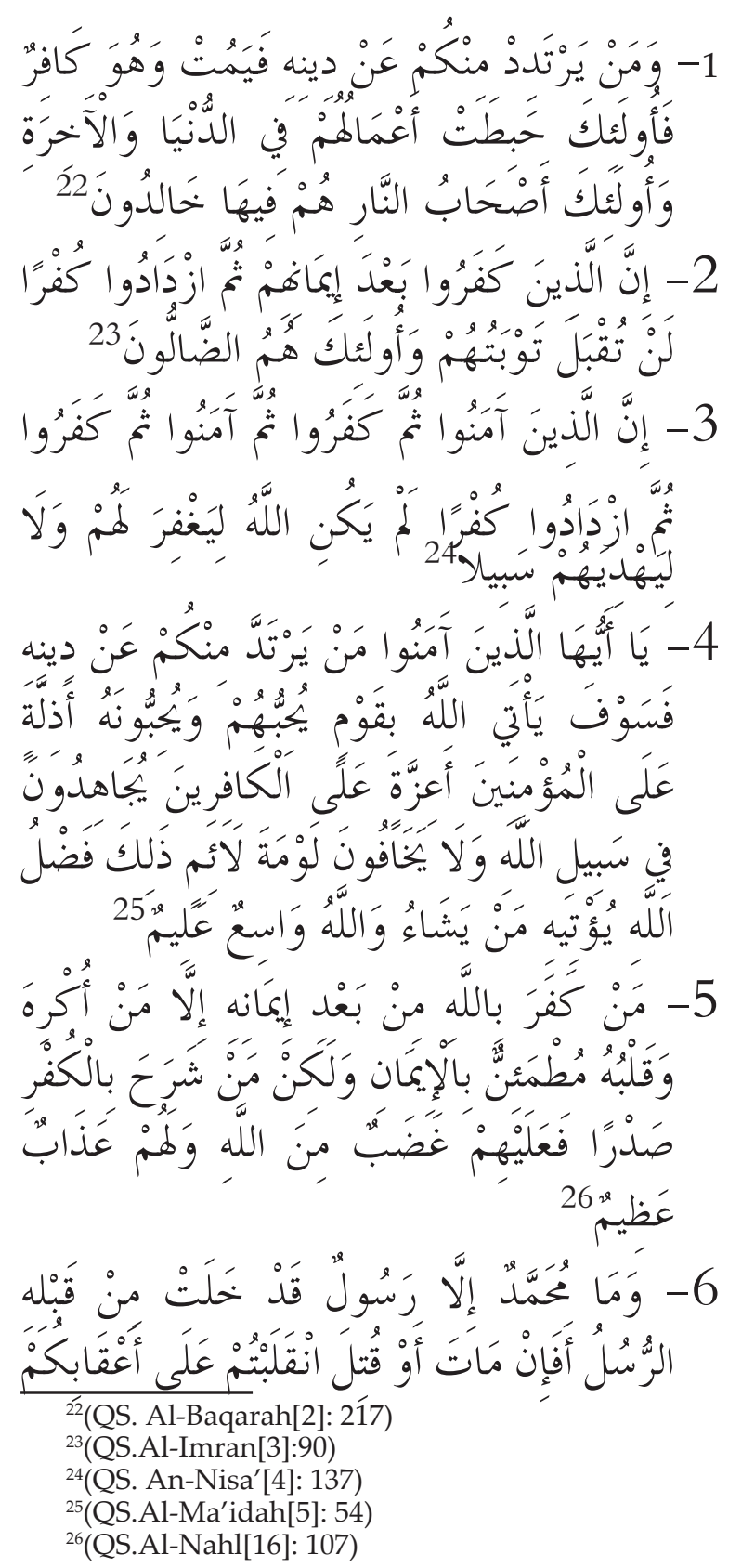

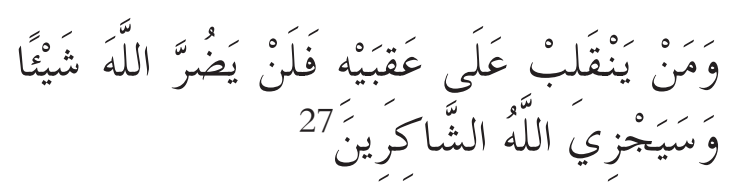

Ayat-ayat di atas adalah ayat-ayat yang menjelaskan tentang hukuman, konsekuensi, dan akibat bagi orang yang memeluk agama Islam kemudian ia keluar dari agama tersebut. Dari beberapa ayat di atas, tidak ditemukan satu ayat pun yang menjelaskan bahwa orang murtad harus dihukum mati. Ayat-ayat di atas menjelaskan bahwa orang yang murtad dan tidak bertaubat itu telah sirna dan terhapus semua amal-amalnya, baik di dunia maupun akhirat, bagi mereka amarah Allah, mereka akan masuk neraka dan kekal di dalamnya.

Dari ayat-ayat di atas, tidak ditemukan satu ayat pun yang menjelaskan bahwa orang murtad itu harus dihukum mati. Berbeda dengan jenis hukuman yang jauh lebih ringan, seperti potong tangan bagi pencuri atau hukum cambuk bagi orang yang berbuat zina.

Penting untuk dikemukakan bahwa meskipun istilah murtad disebut beberapa kali dalam al-Qur'an, namun semuanya tidak menetapkan adanya hukuman apapun. Seandainya al-Qur'an tidak menyebutkan istilah murtad sama sekali, mungkin kita bisa berasumsi bahwa tidak ada kesempatan bagi wahyu Qur'ani untuk menangani hal ini, dan oleh karena itu diserahkan kepada Nabi saw. untuk menanganinya. Mungkin juga perlu dicatat bahwa hampir semua ayat yang menunjuk pada kemurtadan tergolong ayat-ayat yang turun di periode Madinah, ketika negara Islam telah didirikan dan hukuman untuk kejahatan bisa ditentukan dan diterapkan. Dalam hal ini hanya ayat 107 pada surat al-Nahl yang masuk kategori Makiah.

\section{Ketentuan Murtad dalam Hadits}

Kalau kita mencermati hadist- hadist tentang orang murtad di atas, kita dapat

${ }^{27}$ (QS.Al-Imran[3]:145) 
mengelompokkannya menjadi dua bagian. Pertama, hadist-hadist (Khusum) yang menyatakan bahwa orang yang keluar dari agama Islam harus dihukum mati. Kedua, hadist- hadist (Ushul) yang menjelaskan bahwa orang yang keluar dari agama Islam tidak dihukum mati.

\section{Hadist Ushul}

Hadist usul pertama adalah tentang orang badui yang bai'at kepada Rasul untuk masuk Islam dan hijrah dari tempatnya untuk menetap di Madinah. Bai'at kepada Rasul untuk masuk Islam dan berhijrah untuk menetap bersama beliau di Madinah merupakan salah satu contoh pembai'atan Rasul terhadap umat manusia pada waktu itu. ${ }^{28}$ Namun kemudian ternyata badui tersebut ingin membatalkan bai'atnya.

Dari hadist tersebut dapat ditarik beberapa kesimpulan. Pertama, hukuman mati bukanlan hukuman yang harus diterima orang murtad, karena kalau hukuman mati merupakan ketentuan hukum bagi orang murtad, maka orangbadui tersebut tidak akan berani datang ke Rasul untuk memberitahu bahwa ia keluar dari agama Islam. Kedua, dalam hadist tersebut kita melihat Rasul membiarkan orang badui itu pergi begitu saja tanpa memerintahkan kepada para sahabat untuk menangkap orang tersebut untuk dibunuh sebagai bentuk hukuman atau had bagi orang murtad. Padahal sebagaimana kita yakini bersama, bahwa Rasul tidak akan memberikan toleransi, ataupun menerapkan sistem tebang pilih dalam menerapkan hukum Allah. Bahkan, kalau hukum tersebut harus diterapkan kepada putri beliau sendiri. Rasulullah saw. bersabda:

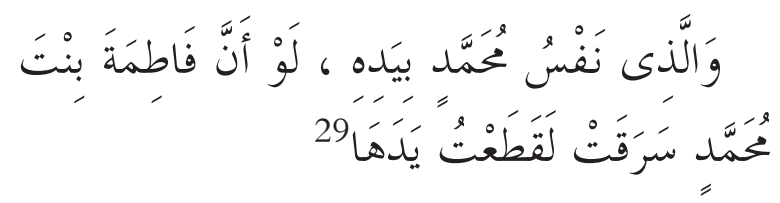

${ }^{28} \mathrm{Ibnu}$ 'Abd al-Barr, al-Istidzkar. (Bairut: Dar alKutub al-Ilmiyah, 2000), vol. 8, h. 224. 4303.
Hadist ushul kedua adalah tentang perjanjian Hudaibiyah. Dalam salah satu isi pasal perjanjian tersebut dinyatakan bahwa orang kafir Makkah yang datang ke Madinah harus dikembalikan. Sebaliknya, orang muslim Madinah yang pergi ke Makkah tidak akan dikembalikan ke Madinah. Perjanjian tersebut dapat dimaknai bahwa andaikan hukuman mati merupakan ketentuan bagi orang murtad, tentu Rasul tidak akan menerima klausul perjanjian tersebut tanpa memandang apakah nanti akan ada orang muslim Madinah yang meninggalkan kota Madinah menuju Makkah atau tidak.

Hadist ushul ketiga, tentang permintaan 'Umar bin Khattab kepada Rasul untuk memenggal kepala 'Abdullah bin Ubay (pemimpin orang-orang munafik yang selalu mengganggu dakwah Rasul, ia juga berhasil membawa pulang sepertiga pasukan Rasul pada waktu perang Uhud), namun Rasul mencegah dan melarang 'Umar untuk membunuhnya.

Hadist ushul keempat, adalah cerita tentang seorang Nasrani yang masuk Islam, ia hafal surat al-Baqarah dan Ali-Imran bahkan ia menjadi salah satu juru tulis Rasul. Kamudian ternyata orang tersebut keluar dari agama Islam dan menjadi seorang nasrani lagi, bahkan pernah mencela Rasul dengan mengatakan bahwa Muhammad itu tidak mengetahui apapun kecuali yang telah aku tuliskan untuknya. Melalui kisah ini bisa diketahui bahwa Rasul tidak membunuhnya ataupun memerintahkan orang untuk menagkapnyadanmembunuhnya. Andaikan hukuman mati merupakan ketentuan bagi orang yang keluar dari agama Islam, maka orang-orang dalam contoh kasus di atas adalah orang yang pantas mendapatkannya karena mereka tergolong orang-orang yang kafir setelah beragama Islam, Allah berfirman:

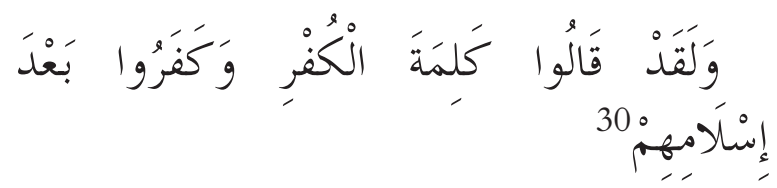

${ }^{30}$ (QS.At-Taubah[9]: 71) 


\section{Hadist Khushum}

Pada hadits khushum yang pertama, kita dihadapkan pada fakta bahwa tidak ada konteks yang diketahui tentang mengapa, dan dalam kasus apa hukum ini ditetapkan, sehingga kita sulit mengetahui latar belakang kemunculan hukum tersebut secara pasti. Yang jelas adalah bahwa hadits tersebut menyatakan bahwa orang yang mengganti agamanya dari Islam menjadi non Islam, maka baginya hukuman mati. Namun, apabila kita melihat kenyataan bahwa Rasul tidak menetapkan hukuman mati pada orang-orang yang keluar dari agama Islam sebagaimana dalam kasus di atas, maka tidaklah tepat apabila hadits ini diartikan secara harfiah dan umum. Artinya kemurtadan an sich bukanlah sebuah dosa yang menjadikan darah seseorang halal sehingga boleh dibunuh.

Pemahaman di atas, akan tampak lebih jelas apabila kita melihat isi dari hadits khusum kedua, yang inti dari salah satu poin dalam hadits tersebut mengatakan, bahwa orang yang halal dibunuh adalah orang yang keluar dari agama Islam, dan bersamaan dengan itu ia juga mufaraqah dengan kaum

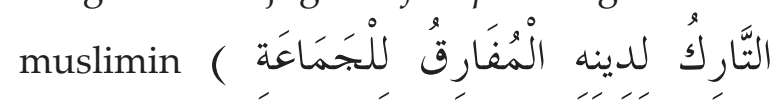
). Andaikan kemurtadan an sich itu bisa menghalalkan darah seseorang, maka semestinya cukup dikatakan al-tarik li dinih. Dengan demikian, penambahan kalimat al-mufariq lil jama'ah memberikan pertanda bahwa orang yang keluar dari agama Islam dan dia tidak mufariq lil jama'ah, tidak cukup syarat untuk mendapatkan hukuman mati.

Ibnu Taimiyah mengartikan al-mufariq lil jama'ah sebagai orang yang memerangi Allah dan Rasul-Nya. ${ }^{31}$ Pemaknaan tersebut didasarkan pada hadits riwayat 'Aisyah sebagaimana di atas, yang salah satu poin dalam hadits tersebut berbunyi:

${ }^{31}$ Ibnu Taimiyah, al-Sarim al-Maslul 'ala Syatim alRasul, vol.I (Bairut: Dar Ibnu Hazm, 1417 H), h.320

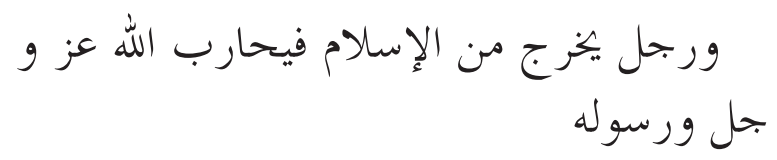

Dari uraian di atas, dapat di tarik kesimpulan bahwa hadits yang menyatakan bahwa orang murtad itu harus dihukum mati, tidak bisa diartikan secara harfiah dan umum. Artinya, keluar dari agama Islam bukanlah sebuah dosa yang menjadikan darah seseorang itu menjadi halal sehingga boleh dibunuh. Hadits yang umum tersebut harus dimaknai bahwa hukuman mati itu hanya berlaku bagi orang-orang murtad yang al-mufariq lil jama'ah. Adapun makna dari al-mufariq lil jama'ah adalah orang yang memerangi Allah dan Rasul-Nya. Jadi hukuman mati tersebut bukan karena kemurtadan seseorang an sich.

A. Dalam suatu riwayat oleh sahabat Anas tentang sikap sahabat 'Umar kepada orang yang murtad dan memerangi orang muslim. Sahabat 'Umar berpendapat bahwa ia akan menawarkan kepada mereka untuk kembali memeluk Islam, dan apabila mereka menolak, maka aku akan memenjarakannya.

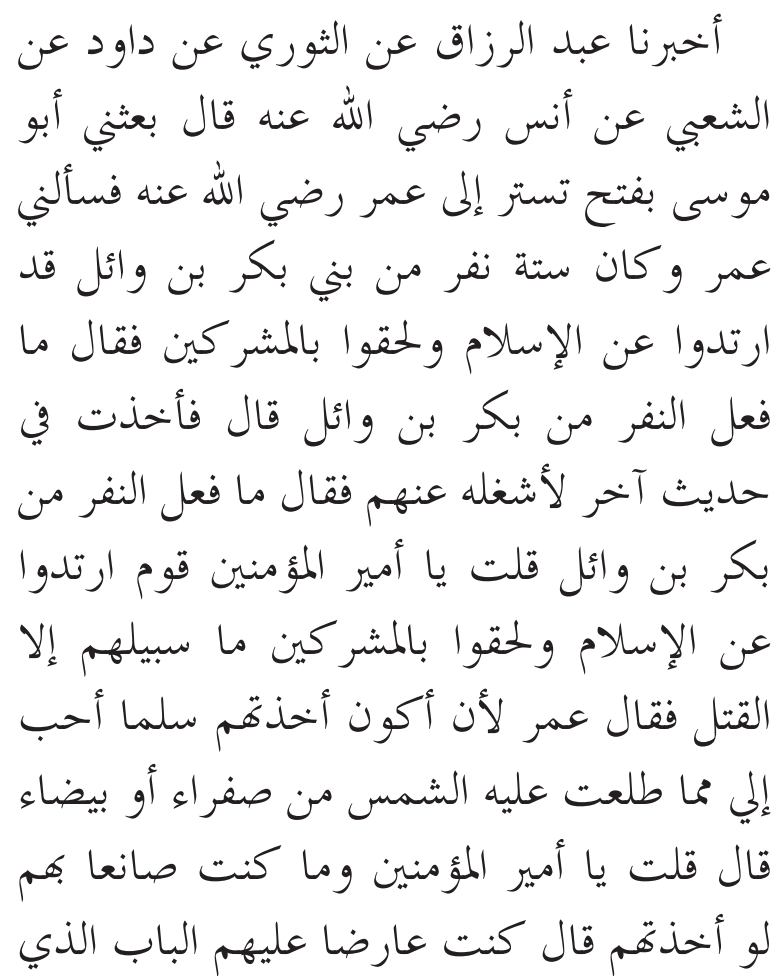


خرجوا منه أن يدخلو ا فيه فإن فعلوا ذلك قبلت 32 .

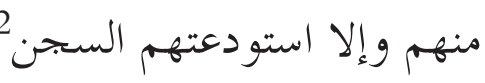

B. Sebuah riwayat yang dikisahkan oleh Ummu Habibah bahwa ia dan suaminya 'Ubaidullah bin Jahsy masuk Islam dan hijrah ke Habasyah, namun kemudian 'Ubaidullah bin Jahsy keluar dari agama Islam dan menjadi seorang Nasrani. Meski ia keluar dari agama Islam, kita tidak pernah menemukan riwayat yang menceritakan bahwa Rasul membunuhnya ataupun memerintahkan kepada seseorang untuk membunuhnya.

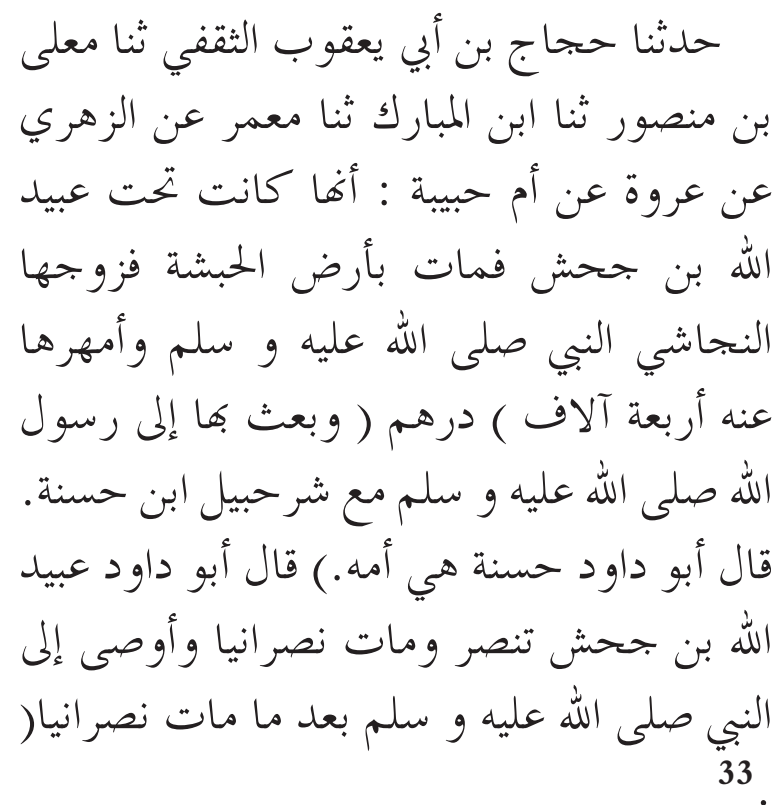

DalamhaliniSyaikhal-Albanimemberikan komentar bahwa ini adalah sahih. ${ }^{34}$

C. Peperangan pada masa awal pemerintahan Abu Bakar, bukanlah perang yang dilancarkan kepada mereka yang keluar dari agama Islam saja .Perang tersebut adalah perang melawan orang yang membangkang dan mengancam setabilitas dan keamanan Negara .Di antara mereka adalah orang-

\footnotetext{
${ }^{32}$ 'Abdu al-Razzaq, Musannaf 'Abdu al-Razzaq, vol. 10 (Bairut: al-Maktab al-Islami, 1403 H), h. 165 Hadith nomor, 18696.

${ }^{33} \mathrm{Abu}$ Dawud, Sunan Abi Dawud, vol.I (Bairut: Dar al-Fikr), h.640, Hadith nomor: 2107.

${ }^{34} \mathrm{Ibid}$, hal.640, Hadith nomor: 2107.
}

orang yang menolak membayar zakat, orang yang murtad dan mengacau keamanan seperti Musailamah al-Kadzdzab yang telah mempersiapkan empat puluh ribu prajurit untuk memerangi kaum muslimin, bahkan sebagian mereka seperti suku 'Abbas dan Dzibyan -menyerang lebih dulu ${ }^{35}$.

\section{Kesimpulan}

Berdasarkan uraian, kajian dan analisa di atas dapat disimpulkan bahwa al-Qur'an sebagai sumber utama dalam Islam tidak pernah menyebutkan bahwa hukuman bagi orang murtad adalah hukuman mati. AlQur'an hanya menjelaskan bahwa orang yang murtad dan tidak bertaubat maka terhapuslahsemuaamal-amalnya, daniaakan menghuni neraka untuk selama-lamanya. Sedangkan hadits tentang hukuman mati bagi orang murtad tidak bisa difahami secara harfiah sehingga setiap orang murtad wajib dibunuh. Hadits tersebut harus difahami bahwa orang murtad yang bisa dibunuh adalah orang murtad yang memerangi Allah dan Rasul-Nya (sebagaimana Hadist yang diriwayatkan oleh 'Aisyah di atas).

Kalau kita mencermati hukuman atau sangsi duniawi yang bersifat fisik, seperti qisas bagi orang yang melakukan pembunuhan, potong tangan bagi pencuri, rajam bagi yang berbuat zina, seluruhnya merupakan hukuman-hukuman yang diundang-undangkan untuk memberikan pembelaan dan menegakkan keadilan bagi orang yang teraniaya. Dan seluruhnya merupakan kejahatan-kejahatan yang barhubungan dengan sesama makluk Tuhan. Adapun keluar dari agama Islam merupakan perbuatan dosa yang tidak memberikan dampak penganiayaan terhadap makhluk Tuhan yang lain. Oleh karenanya, Allah lah yang kelak akan memberikan hukuman pada orang tersebut, sebagaimana yang dikandung oleh ayat-ayat tentang orang murtad itu sendiri. Allahu A'alam bi al-Shawab

${ }^{35}$ Sejarah tersebut bisa dilihat dalam buku-buku sejarah seperti Tarikh Ibnu Khadun dan Tarikh Thabary, pada pembahasan peperangan Abu Bakar di awal masa pemerintahannya. 


\section{Daftar Pustaka}

\section{Al-Qur'an}

Ahmad. Musnad Ahmad bin Hanbal. Kairo: Muassasah Qarthabah, tth.

Abu Dawud. Sunan Abi Dawud. Bairut: Dar al-Fikr, th.

'Abdu al-Razzaq. Musannaf 'Abdu al-Razzaq, tth.

$1417 \mathrm{H}$.

Al-Baihaqi. Sunan al-Baihaqi. Bairut:Dar alFikr, tth.

Al-Bukhari. Shahihal-Bukhari. tth.

Al-Nasa'i. al-Mujtaba min al-Sunan. Halb: Maktab al-Matbu'at al-Islamiyah, 1986.

Al-Suyuthi. al-Jami' al-Kabir. tth.
Al-Turmudzi. Sunan al-Turmudzi. Bairut: Dar Ihya' al-Turath al-'Arabi, tth.

Ibnu 'Abd al-Barr. al-Istidzkar. Bairut: Dar alKutub al-Ilmiyah, 2000.

Ibnu Taimiyah. al-Sarim al-Maslul 'ala Syatim al-Rasul. Bairut:Dar Ibnu Hazm, Muslim. ShahihMuslim. Bairut: Dar al-kutub al'ilmiyah, 1992.

Mahmud Thahhan. Taysir Musthalah alHadist. Maktabah al-Ma'arif, 2004.

Muhammad al-Ghazali. Al-Sunnah alNabawiyyah baina Ahl al-Figh wa alHadist. Kairo: Dar al-Syuruq, 2009.

Yusuf al-Qardlawi. Kayfa Nata'amal ma'a al-Sunnah al-Nabawiyyah. Kairo: Dar al-Syuruq, 2000 